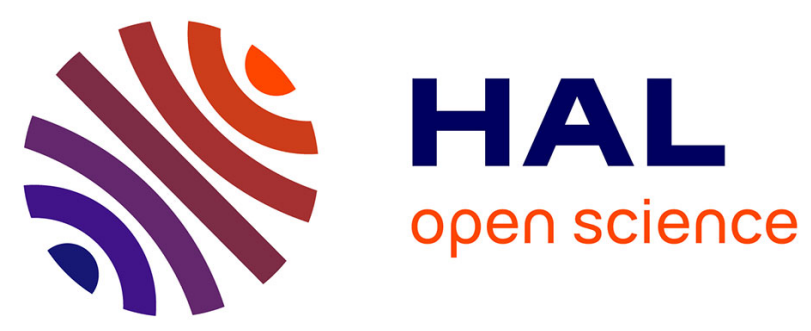

\title{
Continental late Pliocene paleoclimatic history recorded in the Bresse Basin (France)
}

Denis-Didier Rousseau, Nadine Bachiri Taoufiq, Christophe Petit, Geneviève Farjanel, Henriette Meon, Jean-Jacques Puisségur

\section{- To cite this version:}

Denis-Didier Rousseau, Nadine Bachiri Taoufiq, Christophe Petit, Geneviève Farjanel, Henriette Meon, et al.. Continental late Pliocene paleoclimatic history recorded in the Bresse Basin (France). Palaeogeography, Palaeoclimatology, Palaeoecology, 1992, 95, pp.253-261. hal-02864758

\section{HAL Id: hal-02864758 \\ https://hal.science/hal-02864758}

Submitted on 11 Jun 2020

HAL is a multi-disciplinary open access archive for the deposit and dissemination of scientific research documents, whether they are published or not. The documents may come from teaching and research institutions in France or abroad, or from public or private research centers.
L'archive ouverte pluridisciplinaire HAL, est destinée au dépôt et à la diffusion de documents scientifiques de niveau recherche, publiés ou non, émanant des établissements d'enseignement et de recherche français ou étrangers, des laboratoires publics ou privés. 


\title{
Continental late Pliocene paleoclimatic history recorded in the Bresse Basin (France)
}

\author{
Denis-Didier Rousseau ${ }^{\mathrm{a}}$, Nadine Bachiri Taoufiq ${ }^{\mathrm{b}}$, Christophe Petit ${ }^{\mathrm{c}}$, Genevieve Farjanel ${ }^{\mathrm{d}}$, \\ Henriette Méon ${ }^{\mathrm{e}}$ and Jean-Jacques Puisségur ${ }^{\mathrm{f}}$ \\ ${ }^{a}$ Lamont-Doherty Geological Observatory of Columbia University, Palisades, NY 10964, USA and URA 327, Institut des \\ Sciences de l'Evolution, Laboratoire de Paléontologie, Place Eugène Bataillon, 34060 Montpellier, France \\ ${ }^{\mathrm{b}}$ Université Hassan II, Faculté des Sciences II, Département de Géologie, BP 6621, Ben M'Sik, Sidi Othman, \\ Casablanca, Maroc \\ ${ }^{\mathrm{c}}$ Université de Bourgogne, Centre des Sciences de la Terre, 6 Bd Gabriel, 21000 Dijon, France ${ }^{\mathrm{d}}$ Service Géologique \\ National, BRGM, B.P. 6009, 45060, Orléans Cedex 2, France \\ ${ }^{\circ}$ URA CNRS II, Université Claude Bernard, Département des Sciences de la Terre, 27 Bd du 11 Novembre, F-69622 \\ Villeurbanne, France \\ ${ }^{\mathrm{f}}$ Hauteroche, 21150 Les Laumes, France
}

(Received October 29, 1991; revised and accepted April 24, 1992)

\begin{abstract}
Rousseau, D.-D., Petit, C., Taoufiq, N.B., Farjanel, G., Méon, H. and Puisségur, J.-J., 1992. Continental late Pliocene paleoclimatic history recorded in the Bresse Basin (France). Palaeogeogr., Palaeoclimatol. Palaeoecol., 95: 253-261.

We present results to show that the Beaune $\mathrm{P} \& \mathrm{C}$ borehole, cored in the Bresse Basin (France), records late Pliocene climatic variations. Pollen analysis allows precise correlations with northern and southern European stratigraphies. Using Kukla et al.'s (1981) climate index, we show that cold climate phases occur during the Brunssumian, at around 3.2, 3.6 and 5.2 Myr B.P., respectively, in agreement with Atlantic core results. The onset of a general cooling trend is felt early in the Reuverian, at about 3 Myr B.P. which corresponds to the end of a warm event characterized by high percentages of oak. This is followed by minor climatic pulses of increasing magnitude since about $2.7 \mathrm{Myr}$ B.P., that are also recorded in marine sediments. Finally a major cooling occurs at about 2.4 Myr B.P., corresponding to the beginning of the Praetiglian.
\end{abstract}

\section{Introduction}

The Bresse Basin, a geological area located in Eastern France orientated from north to south, lies in an Oligocene tectonic zone (Fig. 1A) belonging to the west-European rift (Bonvalot et al., 1984). The geology is well documented and has been studied intensively, mainly for the late Tertiary and lower Pleistocene deposits (Bonvalot et al., 1984). The structure and morphology of the Bresse Basin show two dissymetries. The first one is a gradient orientated north to south. It shows a decrease of the topographic surface, an

Correspondence to: D.-D. Rousseau, Lamont-Doherty Geological Observatory of Columbia University, Palisades, NY 10964, USA. increase of the thickness of the Tertiary deposits from north to south, and a sharp difference between the plain level and the surrounding borders. This north to south gradient played a main role in the drainage of the basin since the Eocene (Rat, 1984). The second dissymetry is orientated west to east which induced the geometry of the Pliocene-Pleistocene deposits (Rat, 1984). The history of the basin began during the Upper Eocene and the Lower Oligocene. The most important period of tectonic movement and collapse was during the Oligocene. During the Miocene, the north to south gradient is accentuated with deposits in the southern part and the lack of sedimentation in the north. The north tended to uplift while the south continued to collapse. According to Rat (1984), a gap in 


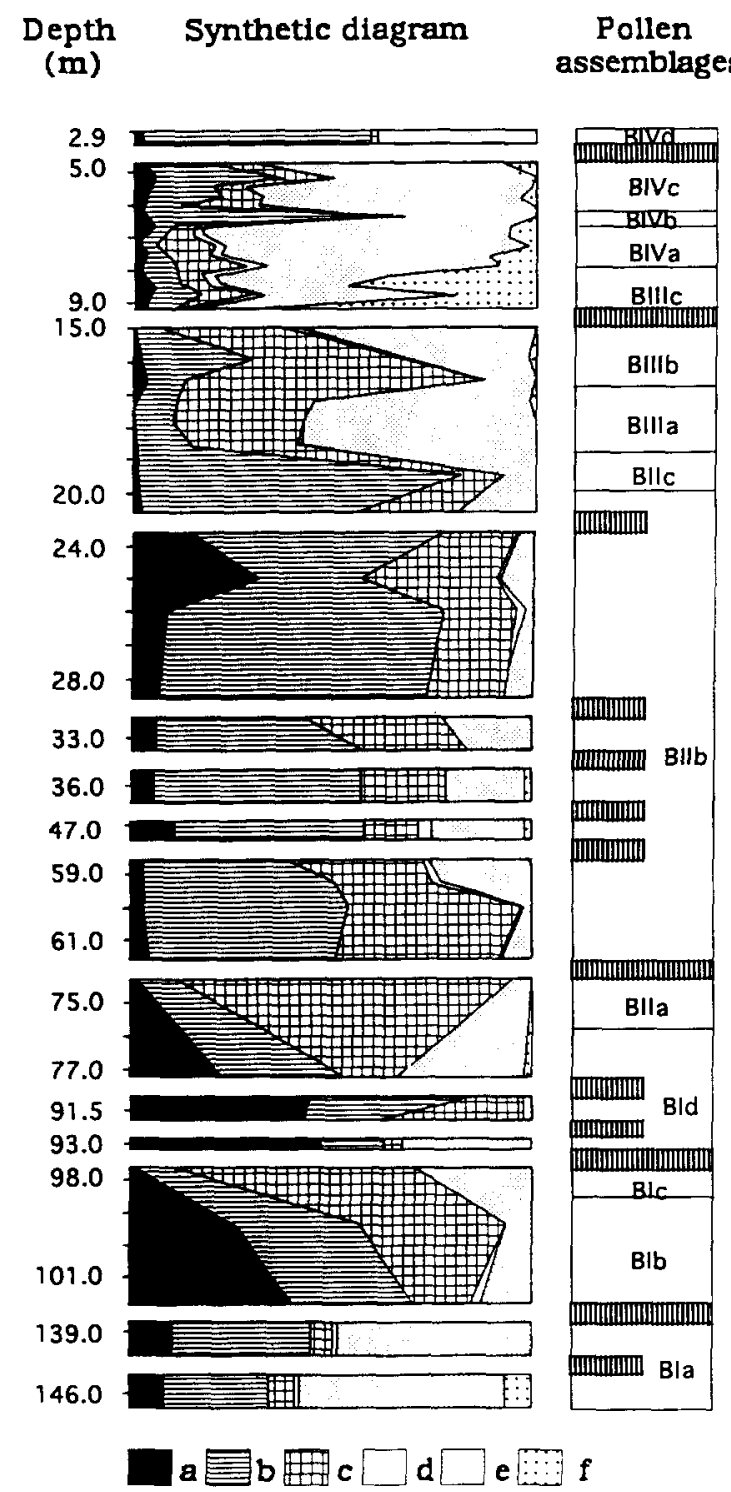

Fig. 2. Synthetic diagram of the Beaune P\&C core. $a=$ Taxodiaceae, Taxodiaceae-Cupressaceae, Engelhardtia, Platycarya, Myrica, Myrtaceae; $b=$ Carvy, Pterocarya, Quercus, Fagus, Carpinus, Ulmus, Alnus, Acer. Tsuga ...; $c=$ Pinus, cf. Cathaya, cf. Cedrus,... Abietaceae; $d=$ Taxa without precise ecological significance (Rosaceae, Plantaginaceae, Labiatae,...); $e=$ aquatic plants, Cyperaceae, Gramineae, Compositae, Amaranthaceae-Chenopodiaceae, Caryophyllaceae, Ephedra; $f=$ Artemisia. (after Bachiri Taoufiq, 1988, modified) The dashed zones correspond to barren sediments.

Four pollen zones are recognized noted BI, BII, BIII, and BIV. The indexes $a-d$ correspond to the different primarily determined sproropollenic assemblages (total of fourteen) in the core.
eae-Chenopodiaceae. Four assemblages are defined (Fig. 2).

- BIa, dominance of AmaranthaceaeChenopodiaceae.

- BIb, dominance of arboreal pollen,

- BIc, dominance of Abietaceae and decrease of Engelhardtia, and other trees except Salicaceae and Ulmus.

- BId, development of TaxodiaceaeCupressaceae, Myrica, cf. Olea.

In the BI zone, the occurrence of thermophilous or mesophilous taxa indicates a warm climate in agreement with the associated molluses (Méon et al., 1989).

The second zone, BII, shows the disappearance of Engelhardtia, Platycarya and Myrtaceae. The spectra indicate high percentages of Abietaceae (mainly Pinus), Quercus, Ulmus, Fagus, Alnus, Carya and Pterocarya. Three assemblages are defined (Fig. 2).

- BIla, disappearance of Engelhardtia, but no reappearance of Quercus.

- BIIb, appearance of Fagus, re-appearance of Quercus, Carpinus, Betula and Pterocarya, present in BIa. Deciduous trees are abundant and diverse. - BIlc, large increase of Alnus and Salix, decrease of Abietaceae. Fagus disappears, as do Carya and Pterocarya.

In the BII zone, the climate is interpreted as being cooler than in the previous BI zone as indicated by the disappearance of the most thermophilous taxa.

The third zone, BIII, shows a clear increase in herbs, Gramineae, Cyperaceae, and Artemisia. Deciduous trees become rare. Three assemblages are defined (Fig. 2).

- BIIIa, herbaceous dominant with Gramineae and Cyperaceae

- BIIIb, herbaceous pollen are abundant but they are not always dominant.

- BIIIc, high percentages of Artemisia in the lower part.

In the BIII zone, the climate is interpreted to becoming progressively colder and drier.

The fourth zone, BIV, shows a progressive increase in arboreal pollen. Four assemblages are defined (Fig. 2). 
- BIVa, herbs still dominate but Artemisia decreases.

- BIVb, large increase of Alnus and Artemisia disappears.

- BIVc, spectra quite similar to that of BIVa.

- BIVd, low percentages of Abietaceae, absence of Taxodiaceae, Alnus, Carya. Trees are only represented by Carpinus, Corylus, Quercus and Myrica which re-appears.

This sequence of palynological change is in agreement with that already defined by Farjanel (1985) and Jan du Chêne (1974) in the Bresse Basin, and by Zagwijn (1975) and Suc (1982, 1984) in northern and southern Europe, respectively. Molluscs assemblages in assemblages BIIIa and BIIIc to BIVd also indicate cool environments, in agreement with the pollen sequence (Méon et al., 1989). The dynamics in the succession of the assemblages appears to be complete, in particular in the upper part, so that correlations can be made with northern and southern reference stratigraphies (Bachiri Taoufiq, 1988; Méon et al., 1989). The sequence spans the time from the Brunssumian to Tiglian periods in agreement with the Zagwijn
(1975) and Suc $(1982,1984)$ stratigraphies and will compensate the absence of palaeomagnetic record in this core. Consequently, zone BI is equivalent to the Brunssumian, BII Reuverian, BIII a and b Upper Reuverian, BIIIc lower Praetiglian, and BIV upper Pratiglian and lower Tiglian (Fig. 3).

\section{Climate index}

In evaluating climatic history from pollen data for periods when megamesothermic taxa are present, the use of transfer functions is not possible. Therefore we use the climatic derived index $(C I)$ proposed by Kukla et al. (1981) to which these authors attribute a global significance.

Its calculation is simple because it includes few but nevertheless climatically significant data. Climatic cycles can be determined like the succession of interglacial to glacial periods. The former, i.e. warm and moist climatic phases, allowed arboreal vegetation to completely develop. During these phases, Quercus $(Q)$ is one of the most significant trees. For the early Pliocene in the diagram, Engelhardtia $(E)$ could be considered to have

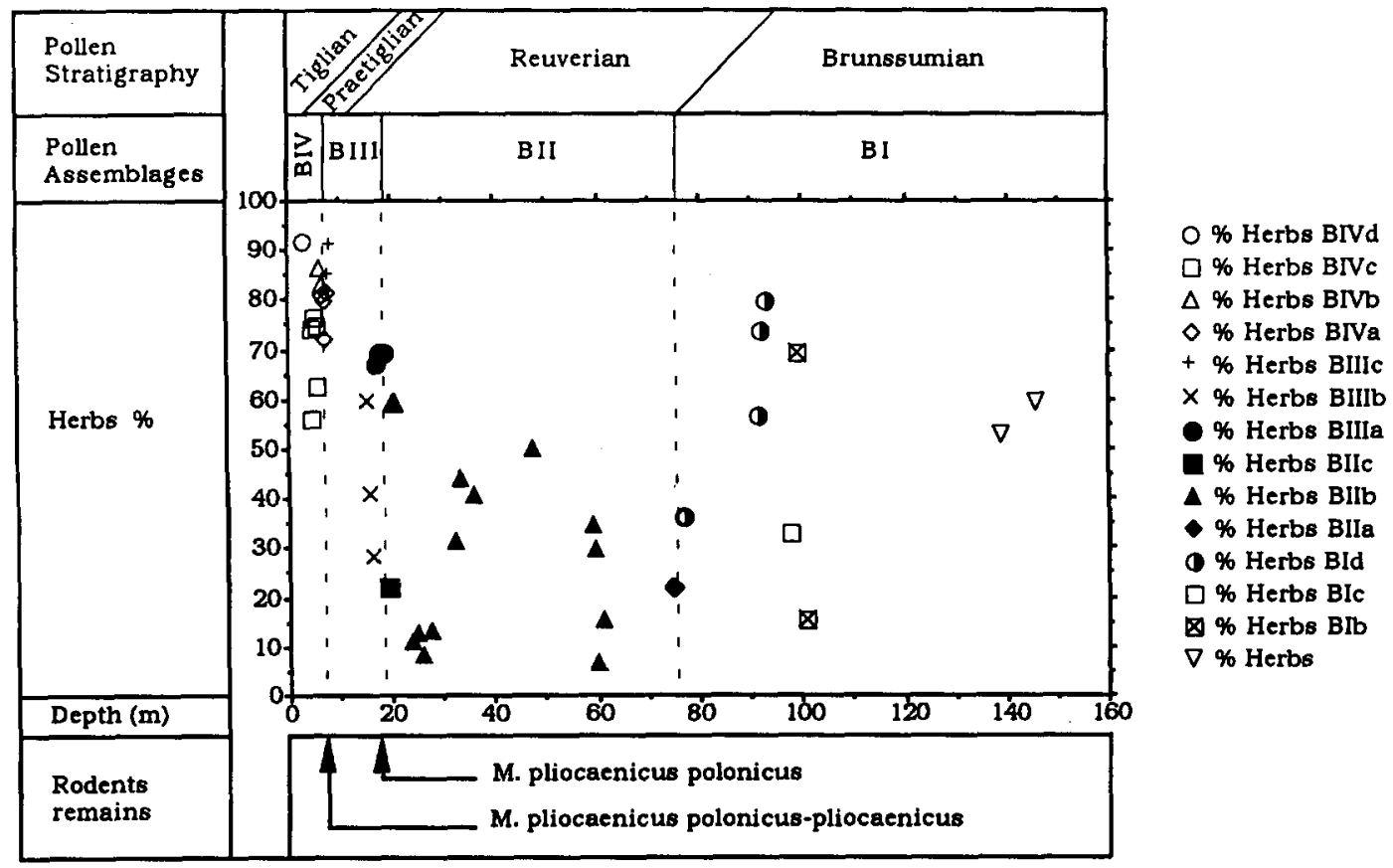

Fig. 3. Variations in herb pollen percentages against depth (in $\mathrm{m}$ ) according to sporopollenic assemblages in European pollen stratigraphy. Location of rodent remains in the core. The different symbols correspond to the initial pollen groups determined by Bachiri Taoufiq (1988). 
played this role. The later phases, in contrast, were extremely long and cold. This resulted in the disappearance of forest and its replacement by steppe vegetation. Thus, herbs characterize these periods. Finally, the transition between warm to very cold periods is the domain of the boreal forest which is characterized by Pinus $(P)$.

In the mid northern latitudes, and particularly in Europe, most of the pollen analyses show that changes in the vegetation throughout the Quaternary roughly corresponded to alternating open environments, mainly with herbs, and forests where Pinus and Quercus dominated. This assumption was used to arbitrarily define the coefficient used for the calculation of the index. For the Beaune $\mathrm{P} \& \mathrm{C}$ core, the Climate Index was calculated as following: $C I=T+2 P+4 Q+4 E$ with $T=$ 100-herbs, P: Pinus, $Q$ : Quercus and E: Engelhardtia. The different coefficients exaggerate the climatic signature of Pinus and Quercus, which never exceed $35 \%$ and $30 \%$ (Fig. 4). Engelhardtia may have played the same role as Quercus during the Brunssumian age (Lower Pliocene), and we assigned a similar coefficient to this taxon. The variations are bounded by 0 . Values approaching zero reflect the climatic signal of a glaciation. The other extreme is 400 , which characterizes warm periods of interglacial character during the late Pliocene and the Quaternary (Fig. 5).

Because of correlations between the Bresse pollen records and northern and southern European pollen stratigraphies, and since the limits of each pollen stage are palaeomagnetically dated (Suc and Zagwijn, 1983) the duration of each stratigraphical unit is interpolated by using a thickness-age ratio controlled by sedimentological and mollusc analyses in the Bresse basin (Petit, 1988, Puisségur, 1984) (Fig. 5). Although we recognize the problem of aliasing in the geological record (Pisias and Mix, 1988), only the results for the portion 2.2-2.8 myr B.P. are discussed in detail.

\section{Results}

By correlation with the precise pollen stratigraphy of western Europe (Suc and Zagwijn, 1983), the Brunssumian, as recorded in the Beaune core, does not provide numerous significant variations if one relies on the above method. The climatic
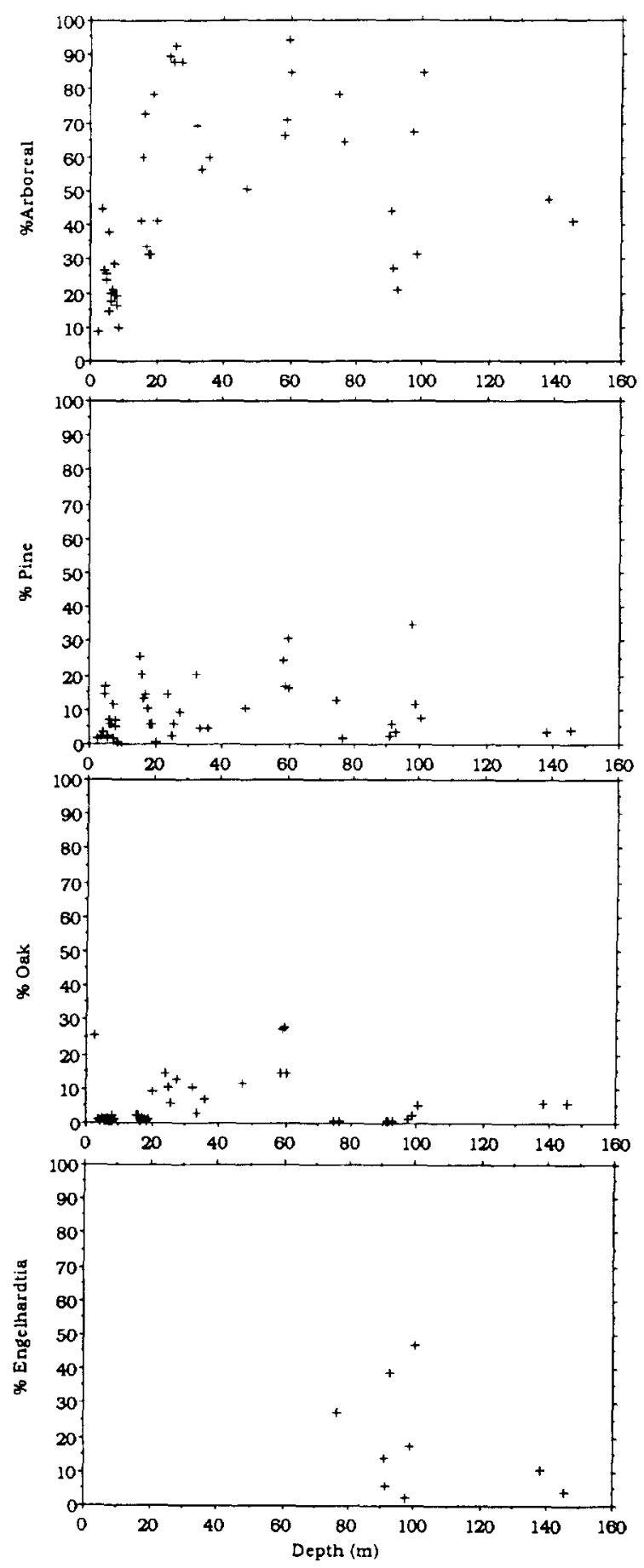

Fig. 4. Variations in total arboreal, Pinus, Quercus and Engelhardtia pollen percentages at the P \& C Beaune core plotted against depth (in $\mathrm{m}$ ). 


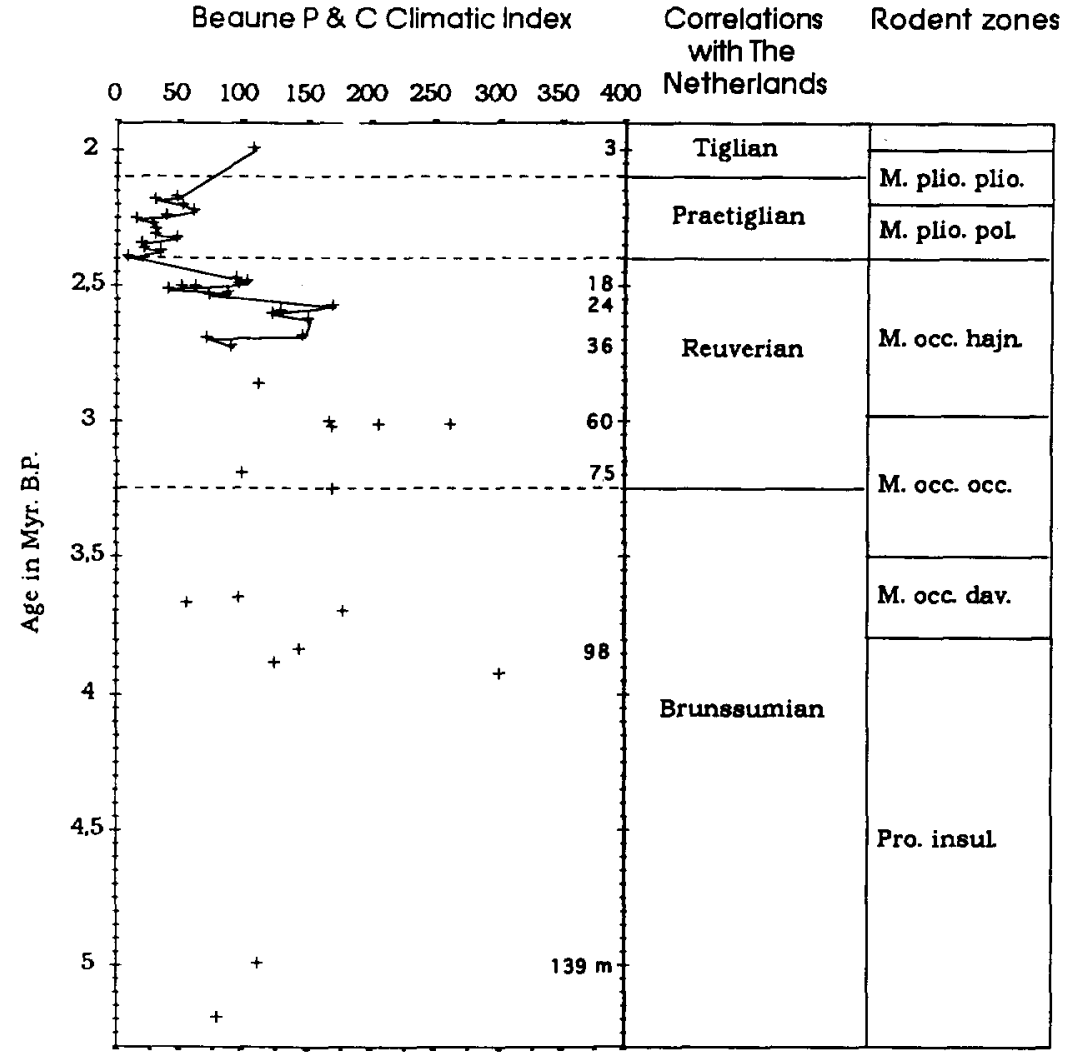

Fig. 5. Variations in Climatic derived Index $(C I)$ at the $\mathrm{P} \& \mathrm{C}$ Core plotted against time and depth. Because of the poor preservation in the lower part of the core, the different calibrated levels were not joined up. The biostratigraphic scale is based on correlations between rodents and palynostratigraphy (after Chaline and Farjanel, 1990; Mein, 1990). M. plio. plio. = Mimomys pliocaenicus pliocaenicus; $M$. plio. pol. $=$ Mimomys pliocaenicus polonicus; $M$. occ. hajn. $=$ Mimomys occitanus hajnackensis M. occ. occ. $=$ Mimomys occitanus occitanus; $M$. occ. dav. = Mimomys occitanus davakosi; Pro. insul. $=$ Promimomys insuliferus.

signal, which is incomplete due to difficulties in sampling cannot be reconstructed more precisely up to the Reuverian (Upper Pliocene). Then the signal is not a linear one but it indicates three minima, with stronger cooling corresponding to younger intervals (Fig. 5). The maximum of cooling is indicated by the extensive development of the steppe formation, in which Artemisia is dominant. This record is important because it indicates the first development (Farjanel, 1984; Méon et al., 1989) of steppe vegetation during the Praetiglian in the Bresse Basin in agreement with northEuropean and Mediterranean data (Suc and Zagwijn, 1983). This cool event occurred throughout mid-low latitudes in Europe.

From pollen stratigraphy, Zagwijn (1992) concluded that the early Quaternary was initiated by a cold event which allowed steppe to develop over large parts of southern Europe. This cold episode, named the Praetiglian, is characterized in the Bresse area by the lack of thermophilous trees, the persistence of Pinus, Betula and Alnus and the high dominance of herbs, especially Artemisia. In the northwestern Mediterranean region, this episode is reflected by a pollen assemblage which indicates a diminishing amount of tree pollen and increasing percentages of Compositae, mainly of Artemisia. This cold episode is dated at 2.4-2.1 myr B.P., and began after the Gauss/Matuyama boundary (Combourieu-Nebout, 1987). This episode, according to Suc and Zagwijn (1983), and Zagwijn and Suc (1984), represents the earliest phase of a cold steppe formation in central and western Europe. This is corroborated by the first appearance of ground-squirrel (Citellus polonicus) and lemmings (Synaptomys europaeus) as well as by the develop- 
ment of vole lineages in Rebielice (Poland) (Chaline, 1973).

What does the Beaune core record (Fig. 5)? The lower part is not very informative because of the badly preserved fossils in the calcareous sediments. Two cold minima seem to occur at around 5.2 and 3.6 m.y. However, such an interpretation could be temperated for the first pollen spectra. Indeed they are rich in Amaranthaceae-Chenopodiaceae (more than $30 \%$ ) which could correspond to an edaphic change resulting in littoral vegetation when the lowermost Pliocene marine transgression reached the Lyon area, which is $140 \mathrm{~km}$ south of Beaune. The intensity of this change is not important compared to the well known Late Pliocene and Quaternary glacial stages. A warm interval is distinguished by high percentages of Engelhardtia at about $3.9 \mathrm{~m} . \mathrm{y}$., which indicates forest development in warm and moist conditions.

A thermal maximum, in the lower Reuverian, at around 3 myr B.P., corresponds to high values of Ouercus, and low values of herbs. Tree pollen exceeds $90 \%, 30.5 \%$ for Pinus. After this warm climate optimum, the signal indicates changes in the climatic trend. Three minima are clearly defined at about $2.7,2.5$ and 2.4 myr B.P. respectively, with an increasing intensity at younger ages. These minima correspond to a decrease of arboreal pollen, low as $9.5 \%$ in the coldest event correlative with the occurrence of Artemisia (Fig. 5).

\section{Discussion}

Is this continental record consistent with other ones on the globe? Indeed similar events in the other parts of the world agree with the main cold event at about 2.4 myr B.P. In North China, the Gauss/Matuyama boundary corresponds to the transition from a coniferous and broad-leaved mixed forest to steppe vegetation ( $\mathrm{Li}$ and Wang, 1983). The pollen study from the Yanqing basin provides a similar result (Qian et al., 1983). Kukla's (1987) study of magnetic susceptibility of loess sequences in Central China also recognized this event which corresponds to the onset of the loess sedimentation on the loess plateau. In Africa, Durand (in Lang et al., 1990) recognizes this event as the onset of aeolian sedimentation in the Lake
Tchad area, in agreement with pollen analyses from East Africa (Bonnefille, 1983; Bonnefille and Vincens, 1985). In Israel, Horowitz (1989) points to a major shift in pollen assemblages at $2.4 \mathrm{myr}$ corresponding to lower temperatures and higher rainfall. In North and South America, this limit also corresponds to changes in the vegetation as revealed by pollen analyses in Tule Lake, California (Adam et al., 1989), and in the BogotaFunza cores, Columbia (Hooghiemstra, 1989).

In addition to these findings in continental records, marine sediments provide data concerning this particular 2.4 myr B.P. event. The first important development of Artemisia occurred during the Praetiglian in the Crotone series (CombourieuNebout, 1990; Combourieu-Nebout and Vergnaud Grazzini, 1991). Data from several cores indicate that a strong cooling occurred at that time. DSDP sites 552 (Zimmerman et al., 1985), 606-609 (Ruddiman et al., 1987b) in the North Atlantic, 657-668 (Ruddiman et al., 1989) in the Eastern Tropical Atlantic, 522 and 523 (Weissert et al., 1984) in the South Atlantic, 576 and 578 (Janecek, 1985) in the Pacific Ocean, ODP sites 642-644 in the Norwegian Sea (Thiede et al., 1989) and 653 in the Tyrrhenian Sea (Rio et al., 1990), indicate that the onset of major ice build-up in the Northern Hemisphere took place at this time. This shift was characterized by a large change in the $\delta^{18} \mathrm{O}$ and $\delta^{13} \mathrm{C}$ values which occurs after the Gauss/Matuyama boundary dated at $2.47 \mathrm{myr}$ B.P. A shift in the mode of eolian deposition from the Asian monsoon, determined from ODP site 721 and 722 in the Arabian Sea (deMonacal et al., 1991) may also associated with this event. Moreover in Atlantic as well as in Mediterranean sequences, the different isotopic curves show the occurrence of several minor peaks, like those of the Beaune $\mathrm{P} \& \mathrm{C}$ record, which correspond in the latter record to climatic pulses. These events indicate a progressive intensity of cooling from early to late Pliocene times. Moreover, recent pollen investigations of the Semaforo series in Italy (CombourieuNebout, 1990; Combourieu-Nebout and Vergnaud Grazzini, 1991) show that since 2.47 myr B.P., the vegetation changes clearly record real interglacialglacial cycles that confirm once more that the climatic events occurring around 2.4 myr B.P. are 
well recorded in both marine and continental sediments. However, Jansen and Sjoholm (1991) found that glaciers were large enough to reach the sea level of the Norwegian Sea since already 5.5 myr B.P.

\section{Conclusion}

Several cooling events in the Beaune P\&C core, of varying magnitude recognized between 3.2 and 2.1 myr B.P., are in agreement with marine, (Atlantic an Pacific Oceans, Mediterranean and Arabian), and continental records. Because they were defined in completely different ways and in different contexts, the correspondence between all these records implies their global value and indicate that the climatic changes may have occurred almost simultaneously in continental and marine environments. This global value thus supports Zagwijn's proposal for the definition of the NeogeneQuaternary boundary at 2.4 myr B.P., as claimed also by Chinese Quaternary stratigraphers, and could recommend a revision of the IUGS (International Union of Geological Sciences) official Pliocene-Pleistocene boundary at 1.66 myr B.P. (27th International Geological Congress Moscow, 1984).

\section{Acknowledgments}

We thank D. Peteet, G. Kukla, W.F. Ruddiman, J.P. Suc, W.H. Zagwijn, P. De Deckker, two anonymous reviewers and $J$. Chaline for their reviews and comments on draft versions of the manuscript. Special thanks to N. CombourieuNebout for unpublished data, D. Peteet, J.P. Suc and W.H. Zagwijn for carefully reviewing the palynological interpretation.

\section{References}

Adam, D. P., Sarna-Wojcicki, A. M., Rieck, H. J., Bradbury, J. P., Dean, W. E. and Forester, R. M., 1989. Tulelake, California: The last 3 million years. Palaeogeogr., Palaeoclimatol., Palaeoecol., 72: 89-103.

Bachiri Taoufiq, N., 1988. Etude palynologique dans le Néogène et le Pléistocène inférieur de Bresse, France (sondage $P$ et $\mathrm{C}$ de Beaune, Côte d'Or). Thesis. Univ. Lyon 1, $120 \mathrm{pp}$. (unpublished).

Bonnefille, R., 1983. Evidence for a cooler and drier climate 487-491.

Bonnefille, R. and Vincens, A., 1985. Apport de la palynologie à l'environnement des Hominidés d'Afrique orientale. In: L'environnement des Hominidés au Plio-Pléistocène. Masson, Paris, pp. 237-278.

Bonvalot, J., Campy, M., Cavelier, C., Chaline, J., Clair, A., Courel, L., Farjanel, G., Fleury, R., Montjuvent, G., Puisségur, J. J. and Rat, P., 1984. Tableaux stratigraphiques proposés pour le Plio-Pléistocène bressan. Géol. Fr, 3: 309-314.

Chaline, J., 1973. Biostratigraphy and climatic fluctuations in the Quaternary on the basis of the rodent fauna. Acta Zool. Cracov., 18: 141-166.

Chaline, J., 1984. La séquence des rongeurs de Bresse, en tant que référence biostratigraphique et paléoclimatique. Géolo. Fr, 3: 251-268.

Chaline, J. and Farjanel, G., 1990. Plio-Pléistocène rodent biostratigraphy and palynology of the Bresse Basin, France and correlations within western Europe. Boreas, 19: 69-80.

Combourieu-Nebout, N., 1987. Place de la première glaciation boréale vis-à-vis de la limite Plio-Pléistocène en Méditerranée. Analyse du Pliocène de Semaforo (Crotone, Italie). C. R. Acad. Sci. Paris, 304, ser. II: 533-538.

Combourieu-Nebout, N., 1990 . Les cycles glaciaireinterglaciaire en région méditerranéenne de -2.4 à -1.1 $\mathrm{Ma}$ analyse pollinique de la série de Cotone (Italie méridionale). Paléobiol. Cont. 17, 35-59.

Combourieu-Nebout, N. and Vergnaud Grazzini, C., 1991. Late Pliocene Northern Hemisphere glaciations: The continental and marine responses in the Central Mediterranean. Qua. Sci. Rev. 10: 319-334.

DeMenocal, P., Bloemendal, J. and King. J., 1991. A rockmagnetic record of monsoonal dust deposition to the Arabian sea: evidence for a shift in the mode of deposition at 2.4 Ma. In: W. L. Prell, N. Niitsuma et al, Proc. ODP, Sci. Res. 117: 389-407.

Farjanel, G,, 1984. Le Pliocène supérieur et le Pléistocène inférieur du Fossé bressan. Apport de la palynologie. Géol. Fr. 3: 269-280.

Farjanel, G., 1985. La flore et le climat du Néogène et du Pléistocène de Bresse (France) d'après l'analyse pollinique. Implications chronostratigraphiques. Doc. BRGM, 97: 1-202.

Hooghmiemstra, H., 1989. Quaternary and upper-Pliocene glaciations and forest development in the tropical Andes: evidence from a long high-resolution pollen record from the sedimentary basin of Bogotá, Colombia. Palaeogeogr. Palaeoclimatol. Palaeoecol., 72: 11-26.

Horowitz, A, 1989. Continuous pollen diagrams for the last 3.5 M.Y. from Israel: vegetation, climate and correlation with the oxygen isotope record. Palaeogeogr. Palaeoclimatol. Palaeoecol. 72: 63-78.

Jan du Chêne, R, 1974. Etude palynologique du Néogène et du Pléistocène inférieur de Bresse (France). Bull. B. R. G. M., 2ème série, 4: 209-235.

Janecek, T. R., 1985. Eolian sedimentation in the northwest Pacific Ocean: a preliminary examination of the data from Deep Sea Drilling Project sites 576 and 548. In: G. R. Heath, L. H. Burckle et al., Init. Rep. DSDP, 86: 589-603. 
Jansen, E. and Sjoholm, J., 1991. Reconstruction of glaciation over the past $6 \mathrm{Myr}$ from ice-borne deposits in the Norwegian Sea. Nature. 349: 600-603.

Kukla, G., 1987. Loess stratigraphy in central China. Quat. Sci. Rev., 6: 191-219.

Kukla, G., Berger, A., Lotti, R. and Brown, J., 1981. Orbital signature of interglacials. Nature, 290: 295-300.

Lang. J., Kogbe, C., Alidou, S., Alzouma, K. A., Bellion, G., Dubois, D., Durand, A., Guiraud, R., Houessou, A., Romann, E., Salard-Cheboldaeff, M. and Trichet, J., 1990. The continental terminal in West Africa. J. Afr. Earth Sci., 10: 79-99.

Li, H. M. and Wang, J. D., 1983. Palaeomagnetic study on drill core from northern Bohai coastal plain. Geochimica, 2: 196-204 (in Chinese with English abstract).

Mein, P., 1990. Updating of MN zones. In: E. H. Lindsay et al. (Editor) European Neogene Mammal Chronology, Plenum Press, New York, pp. 73-90.

Méon, H., Bachiri Taoufiq, N. and Puisségur, J. J., 1989. Analyse sporopollinique du sondage de Beaune (NW de la Bresse, France). Stratigraphie et restitution climatique. Rev. Micropaléontol., 32: 277-292.

Petit, C., 1988. Dynamique des dépôts plio-pléistocènes de la bordure bressane de la plaine beaunoise. Exemple du sondage de Vignolles. DEA Cent. Sci. Terre, Univ. Dijon, 32 pp. (unpublished).

Pisias N. G. and Mix, A. C., 1988. Aliasing of the geological record and the search for long period Milankovitch cycles. Paleoceanography, 3: 613-620.

Puisségur, J. J., 1984. Les faunes malacologiques PlioPléistocènes de la Bresse. Significations écologique, climatique et chronologique. Géol. Fr., 3: 281-302.

Qian, F., Ma, X. H. and Wu, X. H., 1983. Preliminary study on the Quaternary magnetic stratigraphy of China. Mar. Geol. Quat. Geol., 3: 17-29 (in Chinese with English abstract).

Rat, P., 1984. Une approche de l'environnement structural et morphologique du Pliocène et du Quaternaire bressans. Géol. Fr., 3: 185-196.

Rio, D., Sprovieri, R., Thunell, R., Vergnaud Grazzini, C. and Glaçon, G., 1990. Pliocene-Pleistocene paleoenvironmental history of the Western Mediterranean: a synthesis of ODP site 653 results. In: K. A. Kastens, J. Mascle et al., Proc. ODP, Sci. Res., 107: 695-704.

Ruddiman, W. F., Backman, J., Baldauf, J., Hooper, P., Keigwin, L., Miller, K., Raymo, M. and Thomas, E, 1987. Leg 94 paleoenvironmental synthesis. In W. F. Ruddiman,

\section{5}

Ruddiman, W. F., McIntyre, A. and Raymo, M., $1987 \mathrm{~b}$. Paleoenvironmental results from North Atlantic sites 607 and 609. In: W. F. Ruddiman, R. B. Kidd, E. Thomas et al., Init. Rep. DSDP, 94: 855-878.

Ruddiman, W. F., Sarnthein, J., Backman, J., Baldauf, J., Curry, W., Dupont, L. M., Janecek, T., Pokras, E. M., Raymo, M. E., Stabell, B., Stein, R., and Tiedemann, R., 1989. Late Miocene to Pleistocene evolution of climate in Africa and the low-latitude Atlantic: overview of Leg 108 results. In: W. Ruddiman, M. Sarnthein et al., Proc. ODP, Sci. Res., 108: 463-484.

Suc, J. P., 1982. Palynostratigraphie et paléoclimatologie du Pliocène et du Pléistocène en Méditerranée nord-occidentale. C. R. Acad. Sci. Paris, Sér. 2, 294: 1003-1004.

Suc, J. P., 1984. Origin and evolution of the Mediterranean vegetation and climate in Europe. Nature, 307: 429-432.

Suc, J. P. and Zagwijn, W. H., 1983. Plio-Pleistocene correlations between the northwestern Mediterranean region and northwestern Europe according to recent biostratigraphic and palaeoclimatic data. Boreas, 12: 153-166.

Thiede, J., Eldholm, O. and Taylor, E., 1989. Variability of Cenozoic Norwegian-Greenland Sea paleoceanography and Northern Hemisphere paleoclimate. In: O. Eldholm, J. Thiede, E. Taylor et al., Proc. ODP, Sci. Res., 104: 10671118 .

Weissert, H. J., McKenzie, J. A., Wright, R. C., Clark, M., Oberhänsli, H. and Casey, M., 1984. Paleoclimatic record of the Pliocene at Deep Sea Drilling Project sites 519, 521, 522 and 523 (Central South Atlantic). In: K. J. Hsü, J. L. LaBrecque et al., Init. Rep. DSDP, 73: 701-715.

Zagwijn, W. H., 1975. Variations in climate as shown by pollen analysis, especially in the Lower Pleistocene of Europe. Geol. J., 6: $137-152$.

Zagwijn, W. H., 1992. The beginning of the Ice Age in Europe and its major subdivisions. Quat. Sci. Rev., 11.

Zagwijn, W. H. \& Suc, J. P., 1984. Palynostratigraphie du Plio-Pléistocène d'Europe et de Méditerranée nordoccidentales: corrélations chronostratigraphiques, histoire de la végétation et du climat. Paléobiol. Cont. 14: 475-483.

Zimmermann, H. B., Shackleton, N. J., Backman, J., Kent, D. V., Baldauf, J. G., Kaltenback, A. J. and Morton, A. C., 1985. History of Plio-Pleistocene climate in the Northeastern Atlantic, deep sea drilling project hole 552A. In: D. G. Roberts, D. Schnitker et al., Init. Rep. DSDP, 81: 861-875. 